\title{
0905 一様加熱を受ける不均質中空球の一次元熱弾性解析 \\ One-Dimensional Thermoelastic Analysis of an Inhomogeneous Hollow Sphere Subjected to Uniform Heat Supply
}

\author{
○学 中本 向紀（阪府大院） \\ 正 河村 隆介（阪府大院） \\ 正谷川 義信 "(阪府大院)
}

Koki NAKAMOTO, Graduate School of Engineering, Osaka Prefecture University Yoshinobu TANIGAWA, Graduate School of Engineering, Osaka Prefecture University Ryuusuke KAWAMURA, Graduate School of Engineering, Osaka Prefecture University

Key Words: Thermoelasticity, Inhomogeneous Material, Hollow Sphere, One-Dimensional Problem, Uniform Heat Supply

\section{1. 緒言}

著者らは現在まで物性值が座標変数のべき乗形で連続的 に変化する不均質体の弾性および熱弾性問題を理論解析し てきた。直角座標系および円柱座標亲での二次元，三次元問 題はすでに定式化がなされている.しかし,球座標系での定式 化はまだなされていない. そこで，本研究では解析モデルと して不均質中空球を取り上げ，その力学的特性を顕著に表す 一次元問題を理論解析する. 以前までの研究で, 弹性問題 ${ }^{(1)}$ については定式化を行い, 数值計算結果か.ら物性值の不均質 性が応力・変位に及ぼす影響について示した．今回はそれを 熱弾性問題へと拡張して；定式化および数值計算を行う.

\section{2. 熱弾性解析}

\section{1 解析モデル}

熱弾性問題の解析モデルを Fig.1 に示す．Fig.1 では，内半 径 $a$, 外半径 $b$ の中空球の, 内境界での温度および相対熱伝 達率を $T_{a}, h_{a}$, 外境界での温度および相対熱伝達率を $T_{b}, h_{b}$ と して，一様加熱される場合を想定する。

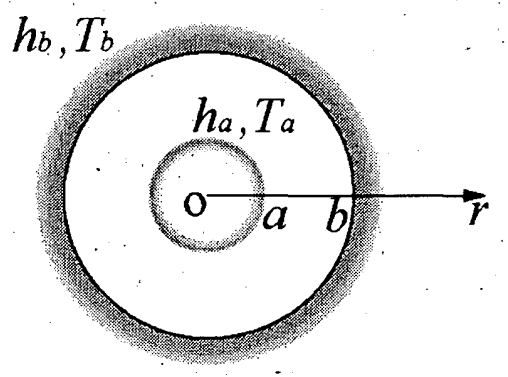

Fig. 1 Conditions and coordinate systems

\section{2 ナビアの方程式の掣出}

球座標系 $(r, \theta, \phi)$ における点対称問題で，ひずみ成分は $r$ 方向の変位を $u_{r}$ とすると

$$
\varepsilon_{r r}=\frac{\partial u_{r}}{\partial r}, \quad \varepsilon_{\rho \theta}=\varepsilon_{\phi \phi}=\frac{u_{r}}{r}
$$

と表され，応力ーひずみ関係は

$$
\left.\begin{array}{c}
\sigma_{r r}=\frac{E}{(1+v)(1-2 v)}\left\{(1-v) \varepsilon_{r r}+2 v \varepsilon_{\theta \theta}-(1+v) \alpha T\right\}, \\
\sigma_{\theta \theta}\left(=\sigma_{\phi \phi}\right)=\frac{E}{(1+v)(1-2 v)}\left\{v \varepsilon_{r r}+\varepsilon_{\theta \theta}-(1+v) \alpha T\right\}
\end{array}\right\}
$$

で与えられる。ここで，Eはヤング率，vはポアソン比， $\alpha$ は線膨張係数， $T$ ，は温度変化である.

また半径方向の力のつり合いは次式のようになる。

$$
\frac{\partial \sigma_{r r}}{\partial r}+\frac{2}{r}\left(\sigma_{r r}-\sigma_{\theta \theta}\right)=0
$$

ここでヤング率 $E$ と線膨張係数 $\alpha$ を次式で定義する.

$$
E(r)=E_{0}\left(\frac{r}{a}\right)^{m}, \alpha(r)=\alpha_{0}\left(\frac{r}{a}\right)^{k}
$$

ただし $E_{0}$ と $\alpha_{0}$ は，それぞれ基準となるヤング率および線膨 張係数， $m$ と $k$ は, それぞれヤング率および線膨張係数の不 均質性を表す任意の数值パラ゙メータである.

式(2)を式(3)に代入して，式(4)を考慮すると

$$
\begin{aligned}
\frac{\partial^{2} \bar{u}_{r}}{\partial \rho^{2}}+(2+m) \frac{1}{\rho} & \frac{\partial \bar{u}_{r}}{\partial \rho}+2\left(\frac{v m}{1-v}-1\right) \frac{\bar{u}_{r}}{\rho^{2}} \\
& =\frac{(1+v)}{(1-v)}\left\{\frac{\partial}{\partial \rho}(\bar{\alpha} \bar{T})+\frac{m}{\rho} \bar{\alpha} \bar{T}\right\}
\end{aligned}
$$

式(5)で導入された無次元量は以下のとおりである.

$$
\rho=\frac{r}{a}, \bar{u}_{r}=\frac{u_{r}}{\alpha_{0} T_{0} a}, \bar{E}=\frac{E}{E_{0}}, \bar{\alpha}=\frac{\alpha}{\alpha_{0}}, \bar{T}=\frac{T}{T_{0}}
$$

ここで， $T_{0}$ は基準となる温度変化である.

\section{3 温度解の隒出}

熱伝導率 $\lambda$ を

$$
\lambda(r)=\lambda_{0}\left(\frac{r}{a}\right)^{l}
$$

で定義すると，一次元点対称定常熱伝導方程式は

$$
\frac{\partial^{2} \bar{T}}{\partial \rho^{2}}+\frac{2+l}{\rho} \frac{\partial \bar{T}}{\partial \rho}=0
$$

ただし， $\lambda_{0}$ は基準となる熱伝導率で， $l$ は熱伝導率の不均質 性を表す任意の数值パラメータである.

式(8)を解いて温度解 $\bar{T}$ を求めると

$$
\bar{T}=D_{1} \rho^{-(1+l)}+D_{2}
$$

となる．ただし $l \neq-1$ であり， $D_{1}, D_{2}$ は熱的境界条件：

$$
\begin{aligned}
& \rho=1 ;: \frac{\partial \bar{T}}{\partial \rho}-H_{a} \bar{T}=-H_{a} \bar{T}_{a}, \\
& \rho=\bar{b} \quad ; \frac{\partial \bar{T}}{\partial \rho}+H_{b} \bar{T}=H_{b} \bar{T}_{b} .
\end{aligned}
$$

から決定される未知定数である。また式(10)で新たに導入さ れた無次元量は以下のとおうである.

$$
\overline{T_{a}}=\frac{T_{a}}{T_{0}}, \bar{T}_{b}=\frac{T_{b}}{T_{0}}, \bar{b}=\frac{b}{a}, H_{a}=a \cdot h_{a}, H_{b}=a \cdot h_{b}
$$

[No.04-40] 日本機械学会第 17 回計算力学講演会講演論文集 〔2004-11.18～20・仙台市 ] 


\section{4 変位·応力の解}

式(9)を式(5)に代入して応力と変位の解を求めると

$$
\begin{aligned}
& \bar{u}_{r}= C_{1} \rho^{\alpha_{1}}+C_{2} \rho^{\alpha_{2}} \\
&+ \frac{1+v}{1-v}\left\{\frac{m+k-1-l}{\left(k-\alpha_{1}-l\right)\left(k-\alpha_{2}-l\right)} D_{1} \rho^{k-l}\right. \\
&\left.+\frac{m+k}{\left(k-\alpha_{1}+1\right)\left(k-\alpha_{2}+1\right)} D_{2} \rho^{k+1}\right\}, \\
& \bar{\sigma}_{r r}=\frac{\rho^{m}}{(1+v)(1-2 v)}\left[\left\{(1-v) \alpha_{1}+2 v\right\} C_{1} \rho^{\alpha_{1}-1}\right.+\left\{(1-v) \alpha_{2}+2 v\right\} C_{2} \rho^{\alpha_{2}-1} \\
&+(1+v) D_{1}\left\{\frac{m+k-1-l}{\left(k-\alpha_{1}-l\right)\left(k-\alpha_{2}-l\right)}\left(k-l+\frac{2 v}{1-v}\right)-1\right\} \rho^{k-l-1} \\
&\left.+(1+v) D_{2}\left\{\frac{m+k}{\left(k-\alpha_{1}+1\right)\left(k-\alpha_{2}+1\right)}\left(k+1+\frac{2 v}{1-v}\right)-1\right\} \rho^{k}\right], \\
& \bar{\sigma}_{\theta \theta}= \frac{\rho^{m}}{(1+v)(1-2 v)}\left[\left(v \alpha_{1}+1\right) C_{1} \rho^{\alpha_{1}-1}+\left(v \alpha_{2}+1\right) C_{2} \rho^{\alpha_{2}-1}\right. \\
&+(1+v) D_{1}\left[\frac{1}{1-v} \frac{m+k-1-l}{\left(k-\alpha_{1}-l\right)\left(k-\alpha_{2}-l\right)}\{v(k-l)+1\}-1\right] \rho^{k-l-1} \\
&\left.+(1+v) D_{2}\left[\frac{1}{1-v} \frac{m+k}{\left(k-\alpha_{1}+1\right)\left(k-\alpha_{2}+1\right)}\{v(k+1)+1\}-1\right] \rho^{k}\right] \\
&\left(k-\alpha_{1}-l \neq 0, k-\alpha_{2}-l \neq 0, k-\alpha_{1}+1 \neq 0, k-\alpha_{2}+1 \neq 0\right)
\end{aligned}
$$

ここで固有值 $\alpha_{1}, \alpha_{2}$ は

$$
\left\{\begin{array}{l}
\alpha_{1} \\
\alpha_{2}
\end{array}\right\}=\frac{1}{2}\left\{-(1+m) \pm \sqrt{(1+m)^{2}-8\left(\frac{v m}{1-v}-1\right)}\right\}
$$

で表される特性方程式の根で, $C_{1}, C_{2}$ は力学的境界条件：

$$
\begin{array}{ll}
\rho=1 ; & \bar{\sigma}_{r r}=0, \\
\rho=\bar{b} ; & \bar{\sigma}_{r r}=0
\end{array}
$$

から決定される末知定数である. また応力の無次元量は以下 のとおりである。

$$
\bar{\sigma}_{r r}=\frac{\sigma_{r r}}{\alpha_{0} E_{0} T_{0}}, \bar{\sigma}_{\theta \Theta}=\frac{\sigma_{\theta \theta}}{\alpha_{0} E_{0} T_{0}}
$$

\section{3. 数値計算例}

2 章で得られた解析解を基に数値計算を行った。一例とし て，計算諸元を次式で与えた。

$$
\begin{array}{ll}
\bar{b}=1.5, & \bar{T}_{a}=\bar{T}_{b}=1.0, \\
\nu=0.3, & H_{a}=H_{b}=\infty
\end{array}
$$

ここでは，不均質性の影響を直接的に見るために，熱伝達は 考慮せずに熱的境界条件を温度指定とした。

計算結果の一例として，それぞれ Fig.2,Fig.3に線膨張係数 の不均質パラメータ $k$ による半径方向変位 $\bar{u}_{r}$, 子午線方向 応力 $\bar{\sigma}_{\theta \theta}$ の変化について示す.

Fig.2 より， $k=0$ の均質体の場合は， $\bar{u}_{r}$ は半径とともに直 線的に増加する. $k=1$ の場合は, 均質体と比較して変位の 絶対值が大きくなる．これは， $k$ が大きくなることで均質体 に比べて球全体の線膨張率が大きくなり，その結果熱ひずみ が大きくなるためである. 一方 $k=-1$ の場合は, 均質体と比 較して変位の絶対值は小さくなる。これは， $k$ が小さくなる ことで均質体に比べて球全体の線膨張率が小さくなり，その 結果熱ひずみが小さくなるためである.

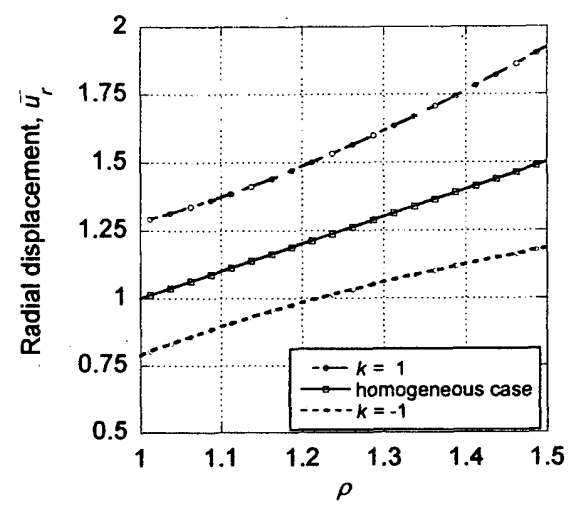

Fig.2 Radial variation of radial displacement $\bar{u}_{r}$ with inhomogeneity parameter $k$

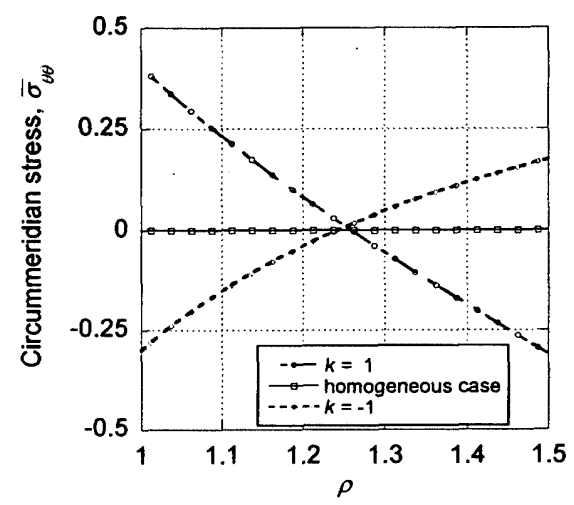

Fig.3 Radial variation of circummeridian stress $\bar{\sigma}_{\theta \theta}$ with inhomogeneity parameter $k$

Fig.3 より， $k=0$ の均質体の場合は， $\bar{\sigma}_{\theta \theta}$ は零となる. こ れは, 両境界同温度で一様加熱しているため自由熱膨張の状 態であるためである. $k=1$ の場合は, 内側で引張応力, 外 側で圧縮応力が発生している.これは線膨張係数 $\alpha$ が半径方 向に大きくなることで, 外側での膨張が内側よりもより大き くなるためである. 一方 $k=-10$ 場合は, 内側で圧縮応力, 外側で引張応力が生じる.これは線膨張係数 $\alpha$ が半径方向に 小さくなることで, 外側での膨張が内側よりもより小さくな るためである.

なお, 紙面の都合上ヤング率に関する不均質パラメータ $m$ および熱伝導率に関する不均質パラメータlの影響につい ては省略する.

\section{4. 結言}

本研究では, 解析モデルとして物性値が半径方向に関して 任意のべき乗の形で変化する不均質中空球を取り上げ, 一次 元熱弾性問題について基礎方程式を定式化した。 また解析解 を基に数值計算を行い，中空球の変位および応力に及ぼす線 膨張係数, ヤング率, 熱伝導率の不均質性の効果について検 討した。

今後は，材料が不均質性と異方性の両方を考慮した場合に 対する問題を取り扱ってゆく予定である.

\section{参考文献}

(1)谷川・中本 - 河村, 機講論, No.03-26 (2003),283-284. 